\title{
Semantic Change Type in Old Javanese Word and Sanskrit Loan Word to Modern Javanese
}

\author{
Hendy Yuniarto ${ }^{1}$ \\ Prof. Dr. Marsono, S.U. ${ }^{2}$ \\ hendyyuniarto@yahoo.com
}

\begin{abstract}
This research aims to describe type classifier of semantic change and to explain the factors causing semantic change. This research was conducted with a qualitative-descriptive approach. The research method is conducted by comparing the meaning of words from the Old Javanese and Sanskrit loan wordto Modern Javanese. The collection data is done by looking for words that the meaning suspected change in Old Javanese dictionary. Words meaning determined precisely by tracing to the Old Javanese text. Furthermore, words meaning are compared to present time meaning through Modern Javanese dictionary. In addition, searching Modern Javanese meaning are also using Javanese news on the internet pages.

The analysis of this research is to classify Old Javanese words and Sanskrit loan words meaning that undergo change to Modern Javanese. It's also explained why the change in the word meaning can occur.

The result shows that, semantic change of Old Javanese words and Sanskrit loan words to Modern Javanese can be classified into seven types, involving widening, narrowing, shifting, metaphor, metonymy, pejoration, andeuphemism. In addition, the result shows that semantic change can occur because of some factors. Psychological factor concerning emotive and taboo, and polysemy. religion spreading, the growth of science and technology, the socio-political development, and the needs of a new name.
\end{abstract}

Keywords: semantic change, Old Javanese, Sanskrit loan word, Modern Javanese, semantic change classification, factor causing semantic change

\section{A. INTRODUCTION}

Every language that living in a civilization must experience a change. Language changes can occur in vocabulary, pronunciation, grammar, and meaning (Trask, 2005:2). Meaning changes can occur in any language because language move on all the time like a wave. From that concept changes of the is an interesting research to be done. This paper discusses the meaning changes of Javanese language.
The main focus of this study is the meaning change of Old Javanese and Sanskrit loan words to Modern Javanese. Research in meaning changes is a diachronic linguistics research or reviewing historical linguistic meaning over time (Campbell, 1998:4). The linguistic scholars have examined meaning change classification. Champbell (1998:254282) classifies the type of changes that include the expansion of meaning, narrowing, metaphor, metonymy, sinekdoke, pejoration, amelioration, taboo, hyperbole, and litotes.

1 Student of the Linguistics Post-Graduate Program, Faculty of Cultural Science, Gadjah Mada University

2 Thesis Advisor, Professor of the Linguistics Post-Graduate Program, Faculty of Cultural Science, Gadjah Mada University 
Problems from the above description is about how the meaning change of words from Old Javanese and Sanskrit loan to Modern Javanese can be classified. The next problem are the factors that cause changes in the meaning of words can occur. Based on the problems, this study aims to describe the types of meaning change of words in the Javanese language and explain the causes. The benefit of this research is theoretically to contribute to the study of meaning change in a language and to know types of meaning change and the causes.

\section{B. RELATED LITERATURE}

Gonda (1952) classify the change of meaning of Sanskrit loanwords into Indonesian. Classification meaning change are restriction and expansion of meaning, metaphor changes, and euphemisms.

Supriyadi Hamam (2010) in his dissertation entitled The Meaning Of Sanskrit Loanwods In Standard Thai And Javanese From Socio-Cultural Perspectives discusses changes to the meaning of the Sanskrit language of Thailand and the change of meaning of Sanskrit into Javanese. The discussion of the meaning of these changes include the classification or classification changes meaning and comparison of changes in the meaning of the Sanskrit to Thailand and Java. Classification of changing the meaning of the Sanskrit to Thailand, among others, restrictions or narrowing of meaning, meaning expansion, and changes of meaning. The classification of the change of meaning of Sanskrit into Javanese among other restrictions or narrowing of meaning, meaning expansion, and changes of meaning.

\section{THEORITICAL FRAMEWORK}

This research using historical linguistics approach which tracing the meaning evolution of a word. The term semantics (taken in the sense of diachronic), is the study of meaning evolution, it also includes an investigation or at least touch on the issues concerning the process of losing, loss, survive, and sometimes even the revival of speech units, up led to the creation of new forms and new words (Gonda, 1952:328).

\section{a. Word and Meaning Concept}

In the dictionary we can see the words which is free from the context. Each word has a one meaning or more. Meaning attached to each word is a reciprocal relationship. Leech (1974:10-27) divides meaning into seven types: conceptual meaning, connotative meaning, stylistic meaning, affective meaning, reflective meaning, and thematic meaning. Reflective meaning, stylistic, and affective incorporated within the scope of associative meaning.

\section{b. Conponential Meaning Analysis Concept}

Meaning in each word has a number of components. Each component is a features that distinct. The term of meaning component analysis is often used for describing the meaning of the word that analysis into contrastive elements (Leech, 1974:98). In the analysis of the components used sign $(+)$, $(-)$. Sign $(+)$ is used to express the meaning of components that owned by a word. Sign (-) is used to express componential meaning that are not owned by a word.

\section{c. Meaning Change Type}

The meaning change type in this research divides in two criteria, conceptual and association. Conceptual meaning include widening, narrowing, and shifting. Association meaning include changes in the meaning of metaphor, metonymy, pejoration, and euphemism.

\section{METHOD OF THE STUDY}

The research is limited to Javanese words included in Sanskrit loan words in the dictionary of Zoetmulder (1982) 
and Mardiwarsito (1990). This research conducting by using seven Javanese texts including those in the dictionary that dates from about the 10th century until the 15th century. Modern Javanese data source is Javanese language dictionary of Poerwadarminta (1939) and Prawiroatmojo (1994), while the text as the source of Modern Javanese are several web pages. The data sources can be itemized as follows.

\begin{tabular}{|c|c|c|c|}
\hline $\begin{array}{l}\text { Old Javanese } \\
\text { Dictionary } \\
\text { - Zoetmulder } \\
\text { (1982) (KJK) } \\
\text { - Mardiwarsito } \\
\text { (1990) }\end{array}$ & $\begin{array}{l}\text { Modern Javanese } \\
\text { Dictionary } \\
\text { - } \text { Poerwadarminta } \\
\text { (1939) } \\
\text { - } \text { Prawiroatmojo } \\
\text { (1994) } \\
\text { - } \text { Roorda (1847) }\end{array}$ & $\begin{array}{l}\text { Old Javanese Texts } \\
\text { - } \text { Ramayana (RY) } \\
\text { - A r ju n a w i wā h a } \\
\text { (AW) } \\
\text { - A r ju n a w i j a y a } \\
\text { (AWj) } \\
\text { - Nāgarakrtāgama } \\
\text { (Nag) } \\
\text { - Sutasoma (Sut) } \\
\text { - B ha r a ta y u d h a } \\
\text { (BY) } \\
\text { - Bhomāntaka (BK) }\end{array}$ & $\begin{array}{l}\text { Modern Javanese Web Pages } \\
\text { - www.manteb.com } \\
\text { - www.panjebarsemangat.co.id } \\
\text { - www.romansecuil.blogspot.com } \\
\text { - www.harianjogja.com }\end{array}$ \\
\hline
\end{tabular}

The method of analysis is done by comparing the Old Javanese and Modern Javanese words that undergo meaning change. The next step is to classify the meaning changes. The last step is to explain why the change of meaning can occur. The overall method shows that this research is descriptive qualitative research that describes and explains the change in meaning.

\section{E. RESULT}

a. Meaning Change Classification from Old Javanese and Sanskrit words into Modern Javanese

This research divides semantic change into two criterion, conceptual and association .

\section{1) Conceptual Meaning Change}

Conceptual meaning (sometimes called the meaning of 'denotative' or 'cognitive') in the broad sense is considered a central factor in the communication language (Leech, 1974:19). The conceptual meaning change can be divided into three types, widening, naroowing, and shifting . These types is described as follows.

\section{(a) Widening}

Widening is the meaning changes which is meaning in the present more widely used than the previous meaning (Ullmann, 1972:230). The Old Javanese word bela is a verb which means "compassionate manner suicide, risking his life to someone or for someone else"(Zoetmulder, 1982:239; Mardiwarsito, 1990:113). The word bela found in Old Javanese text quote as follows.

- Sangkěp sang māntra mantri saha bala bala lawan wallabhana kang pwabela. (AW 7.1)

"all the kings and followers ready, the minister and the powerful army, all of them risk their lives".

Now the word bela in the Modern Javanese means "condolences or share his misery". Meaning change that occur in the word bela is widening. Here is an example of a sentence using the word bela in Modern Javanese.

- Pagelaran seni digelar ing alun-alun kutha Temanggung kanthi lakon Ki Ageng Mangir kang nyritakake perjuangane Ki Ageng Mangir jrone mbelani rakyate. (http://manteb.com/berita/4763/) 
"Art exhibition held in the town square with the play Ki Ageng Mangir which telling $\mathrm{Ki}$ Ageng Mangir struggle to defend its people".
The meaning change of bela can be seen through componential changes. The components of the change are as follows.

Word

\section{Old Javanese Componential Meaning}

bela

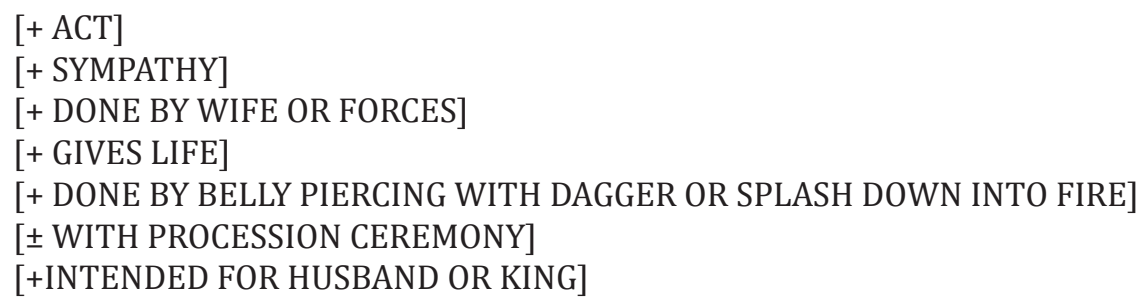

Modern Javanese Componential Meaning

$[+\mathrm{ACT}]$

[+ SYMPATHY]

[ + CAN DONE BY EVERYONE]

[ \pm GIVES LIFE]

[ + TAKING ANY ACTION OF SYMPATHY]

[+ CAN BE INTENDED FOR ANYONE]

\section{(b) Narrowing}

Narrowing or restriction occurs when the coverage is now more limited meaning than when in the past (Ullmann, 1972:228). The Old Javanese word layat is a verb which mean "go to, leave" (Zoetmulder, 1982:998; Mardiwarsito, 1990:314). The meaning of layat can be seen by quote in following text.

- Sarāt maling awěh layat awědi riśakti sang prabhu. (BY 1.5)

"all the thief disappeared scared away because of the king's power".

layat changes it's meaning as in Java Modern mean "go to the people who were left to die" (Poerwadarminta, 1939:256; Prawiroatmojo,
1994:259). Here are examples of layat that used in a Modern Javanese sentence.

- Korban kang arep mulih lannglayat bapake kang tinggal donya iki kakira ora eling amarga ngombe jamu kang ditawakake dening pelaku aksi bius. (http://manteb.com/berita/1027/)

"victims that go home and mourn the deceased father can not remember because herbal drink offered by the perpetrators of trafficking".

Narrowing meaning of the word layat can also known through it's componential changes. The representation of componential changes are as follows.

\footnotetext{
Word Old Javanese Componential Meaning

layat $\quad[+\mathrm{ACT}]$

[+ GO FROM ONE PLACE TO ANOTHER PLACE]

Modern Javanese Componential Meaning

[+ ACT]

[+ MAKE A VISIT OF CONDOLENCE]
} 


\section{(c) Shifting}

A word on the progress of time will experience meaning shifting so now little to know the meaning of the beginning, even did not know the meaning of beginning again. The word rabi in the Old Javanese word is a noun meaning "wife, couple" (Zoetmulder, 1982:1470; Mardiwarsito, 1990:455). The word rabi found in Old Javanese text quote as follows.

- Tan huningān sinandhing i rabinya mangamĕr anisik sake wuri (AW 15.14)

"not ignored when next to her wife, caressing, hugging from behind".

Kata rabi mengalami pergeseran makna sebagaimana pada saat ini kata tersebut dalam Jawa Modern memiliki makna "menikah" (Poerwadarminta,1939:515). Kata rabimengalami perubahan kelas kata, jadi kelas katanya berubah yaitu dari nomina ke verba. Berikut ini contoh pemakaian kata rabidalam kalimat Jawa Modern.

- Sasuwene yang-yangan, tersangka kang wisrabi iku tau moto korban kang lagi wuda nganti ping pindho. (http://manteb. com/berita/5043/)

"during courtship, a suspect who has been married even take a picture of victim when was naked two times".

Meaning change of the word rabi also involves change of the meaning componential. Componential change can be represented as follows.

\section{Word \\ Old Javanese Componential Meaning \\ Rabi \\ [+ SPOUSE] \\ [+ WIFE] \\ Modern Javanese Componential Meaning \\ $[+\mathrm{ACT}]$ \\ [+ GET MARRIED]}

\section{Association Meaning Change}

Meaning changes in associative criteria include metaphor, metonymy, pejoration, and the and euphemism. These types are described as follows.

\section{(a) Metaphor}

A metaphor shows changes between two things that are based on the perceived similarity (Fortson, 2003:648). The Old Javanese word pěgat is a verb means "broken, finished, and perfect" (Zoetmulder, 1982:1333; Mardiwarsito, 1990:417). The meaning of pěgat is known by the following text citations.

- Wwantěn boddha mahāyanabrata pěgat ring tantra yogīswara. (Nag, 68.2)

"There is a Mahayana Buddhists, who had been perfect in tantra and the leader of the yogi".
Pěgat experience meaning change of metaphor that removes the sense of breaking into a divorce. In the Modern Javanese we now that pěgat has a meaning "divorce" (Poerwadarminta, 1939:482). Here is the examples of pěgat in Modern Javanese citation.

- Nanging wanita kang duwe anak 1 kasebut dipesthekake wis dadi randha amarga dipěgat dening bojone ing saperangan taun kepungkur. (http://manteb.com/ berita/389/)

"But women who have a child likely have been widowed since divorced by her husband a few years ago".

Change in the meaning componential of pěgat can be represented as follows. 


$\begin{aligned} \text { Word } & \text { Old Javanese Componential Meaning } \\ & {[+ \text { ACT }] } \\ \text { Pěgat } & {[+ \text { CUTTING ACQUIAINTANCE WITH }] } \\ & {[+ \text { FINISH }] } \\ & \text { [+ COMPLETE }] \\ & \text { Modern Javanese Componential Meaning } \\ & {[+ \text { ACT }] } \\ & {[+ \text { CUTTING ACQUIAINTANCE WITH SPOUSE }] } \\ & {[+ \text { DIVORCE }] }\end{aligned}$

\section{(b) Metonymy}

When a piece of something stands for the whole thing or when something associate on something else for each other is Metonymy (Janda, 2006:21). Kalpataru is a Sanskrit loan word as nouns in Old Javanese means "one of the five trees in Indra's paradise or tree of abundance" (Zoetmulder, 1982:446). Kalpataru found in the following text.

- Wwantěn ramyaracana śūnya kāwakanya, ngkaněng kalpataru paran sang arya Pārtha.(AW 17.3)

"There is a beautiful building, quiet, and alone, that's the Arjuna toward to kalpataru tree".
In the development of the Modern Javanese, the word kalpataru mean "an award in the form of golden trees that dedicated to province". The use of kalpataru in a sentence is as follows.

- Kanggo Kalpataru Jawa Timur nampa anugrah cacah 2, saka 10 penghargaan Kalpataru kang dibagekake. (http:// www.panjebarsemangat.co.id / jawa-timur-mborong-penghargaanlingkungan-taun-2011)

"For Kalpataru East Java received a gift as much as 2, from 10 pernghargaan distributed".

Changes in the meaning of Kalpataru can be represented as follows.

$\begin{array}{cl}\begin{array}{c}\text { Word } \\ \text { kalpataru }\end{array} & \begin{array}{l}\text { Old Javanese Componential Meaning } \\ {[+ \text { TREE }]}\end{array} \\ & {[+ \text { MYTH }]} \\ & {[+ \text { HINDU }]} \\ & \text { Modern Javanese Componential Meaning } \\ & {[+ \text { APPRECIATION }]} \\ & {[+ \text { TREE }]} \\ & {[+ \text { GOLD COLOURING }]} \\ & {[+ \text { SYMBOL }]}\end{array}$

\section{(c) Pejoration}

A word that changes the meaning of pejoration have more negative value than in the past. In Old Javanese, babu is a noun mean "mother or elderly woman who worked as a nanny" (Zoetmulder, 1982:183; Mardiwarsito, 1990 : 104). Babu found in the following quote.
- Tiga pahutangan ing janma mānusa haneng bhūloka, bapa babu bhathāra. (KJK 183)

"three place that human owe on earth, father, mother, and god".

In the Modern Javanese, babu has meaning "worker devoted to his master" (Poerwadarminta, 1939:23). Here is an example of a sentence using the word $b a b u$ in Modern Javanese. 
- Uripmu isih klebu beja, katimbang dadi babu ing manca, kurang bejane dipilara. (http://www.panjebarsemangat.co.id/ geguritan-322012)
"Your life is fortunate, rather than a lowly worker abroad, if less fortunate will tortured".

Changes in the meaning of babu can be represented as follows

\author{
babu \\ Word Old Javanese Componential Meaning \\ [+ MOTHER] \\ [+ WOMEN] \\ [+ OLD] \\ [+ CARETAKER] \\ [- NEGATIVE VALUE] \\ Modern Javanese Componential Meaning \\ [+ WORKER] \\ [+ LOW STATUS] \\ [+ NEGATIVE VALUE]
}

\section{(d) Euphemism}

Euphemism is an expression that refers to any act or event someone has doubts as to say plainly as fears making mistakes or painful. In Old Javanese a word gusti is a noun mean"lord, noble, or a particular group in society official palace" (Zoetmulder, 1982:564). Gusti is found in Old Javanese text excerpt as follows.

- Tandha mwang gusti wadwā haji muwah ikang amwang tuhan ringyawābāp. (Nag 9.2)

"The ministers, nobles, the king and the king's servants are very much in the outside".
Gusti changes it's meaning as euphemism in Modern Javanese. Gusti has extra meaning to the use for the refinement of "god" (Poerwadarminta, 1939:157). Here are examples of gusti in a Modern Javanese sentence.

- Mbak Uci nyuwun tambahing donga lan pangestu, mugi tansah nampi berkahing Gusti, tansah sehat lan benjing dados lare ingkang bekti dhateng Gusti. (http:// www.panjebarsemangat.co.id/lucia-eka) "Uci pleading prayer and blessing, may always accept God's grace, always healthy and tomorrow being a dutiful son to God". Changes in the meaning of gusti can be represented as follows.

\footnotetext{
Word

Old Javanese Componential Meaning

gusti

[+ CLASS $]$

[ + NOBLEMAN]

[ + NOBLEMAN ADDRESSING]

Modern Javanese Componential Meaning

[ + CLASS $]$

[ + NOBLEMAN]

[ + NOBLEMAN ADDRESSING]

[ + ADDRESSING FOR GOD]
} 


\section{b. Causes of Changes in Old Javanese word meaning and Sanskrit into Modern Javanese}

Factors that causing changes in the meaning of Old Javanese and Sanskrit words into Modern Javanese is divided into two: internal factors and external factors.

\section{1) Psychological Factor}

Ullmann (1977:200) mentions that the psychological factor is one of the factors causing the change of meaning. Psychological factors covering emotive factors and taboos in it. Wuyung in Old Javanese means "peace of heart disorders, grief, anger, sorrow". Later, the meaning changes in Modern Javanese "falling in love."

\section{(a) Polysemy}

Campbell (1998:268) states that meaning changes must pass through a stage polisemi. A word starts with an original meaning, then gained an additional meaning and even the original meaning can be lost. Alternatively in a change of meaning, in the form of a word polysemy may lose one or more meanings. The first stage is when a word has a meaning $\mathrm{A}$. The second stage is a word have additional meanings that have meaning $\mathrm{A}$ and $\mathrm{B}$. The third stage is a word to change the meaning of the loss of meaning that only the left only has meaning in a word. An example is the word tambak in Old Javanese meaning "wall." Next steps, tambak means "retaining wall of fish in the water". Stage last words lose their meaning embankment wall earlier, so at the present time has a meaning "fish pond the river or the sea".

\section{(b) Spreading Religion}

The spreading of Islam in Java is one of the important cultural changes in Javanese society. In connection with the change of language, particularly changes the meaning of words in the
Javanese language, some words change in the meaning caused by the spreading of Islam. A word ngaji "reading and studying religious texts, especially the Hindu-Buddha" experience meaning changes to Modern Javanese which mean "reading and studying religious texts, especially the religion of Islam "because it changes the meaning of the majority of transitional religions, from HinduismBuddhism to Islam.

(c) The Development of Science and Tachnology

The development of science and technology resulting a word can have a meaning related to the renewal of the technology compared to the reference old meaning. When new technology is found then a new reference will added. Old Javanese word daluwang "bark" change it's meaning to odern Javanese dluwang mean "paper" is an example of innovation in the field of technology. At first bark called daluwang in Old Javanese texts are used as a cover or cloths. It is also used as clothing in Hindu religious ceremonies (Pigeaud, 1967:35-36).

(d) The Development of Social and Politics

In context with the change of meaning, there are several words changes it's meaning caused by social and political development. Old Javanese word buruh "mercenary" change it's meaning become "paid workers" because of rising social and political community.

\section{(e) The need for a new name}

The human thought continues accordance with their needs, whereas a new invention also need a new word or naming for communication (Pateda, 2001:167). Thoughts, ideas and concepts are unlimited but the words are limited so people need new words. At first in Old Javanese, a word brěm is a liquor made from fermented rice. But in the end brěm 
in Modern Javanese is used to name the new concept as the food of fermented rice compaction without alcohol.

\section{F. CONCLUSION}

Meaning changes in the Old Javanese and Sanskrit word can be generally classified into two categories, namely conceptual and associations. Conceptual includes three types of meaning extension, narrowing, and shifting. Association includes four types, namely metaphor, metonymy, pejoration, and euphemism. The change of meaning due to several factors. Some of these factors are psychological factors that include factors taboo and emotive factors, polysemy, religious development, the development of science and technology, social and political developments, and the need for a new name.

\section{REFERENCES}

Champbell, L., \& Mauricio J. M. 2007. A Glossary of Historical Linguistics. Edinburg: Edinburg University Press.

Gonda, J. 1952. Sanskrit InIndonesia.Nagpur: The InternationalAcademy of Indian Culture.

Leech, G. 1974. Semantics. England: Penguins Books.
Mardiwarsito. 1990. Kamus Jawa Kuna Indonesia. Flores: Nusa Indah.

Pateda, M. 2001. Semantik Leksikal. Jakarta: PT Rineka Cipta.

Pigeaud, T. 1967. Literature Of Java.Volume 1. Leiden: The Hague, MartinusNyhoff.

Poerwadarminta,W.J.S.1939. Baoesastra Djawa. Batavia: J.B Wolter's Uitgevers Maatschappij n. V. Groningen.

Supriyadi, H. 2010. The Meanings of Sanskrit Loan Words in Standard Thai and Javanese from Socio-Cultural Perspectives. Disertasi.Nakhorn Pathom: Mahidol University.

Trask, R.L. 2005. Language Change. London and New York: Routledge.

Ullmann, S. 1972. Semantics An Introduction To The Science of Meaning. Oxford: Basil Blackwell. . 2007. Pengantar Semantik (diadaptasi oleh Sumarsono). Pustaka Pelajar: Yogyakarta.

Zoetmulder, P.J. 1983. Kalangwan: sastrajawa kuno selayang pandang, terjemahan Dick Hartoko. Jakarta : Djambatan. P.J. 1982.Old Javanese-English Dictionary, jilid 1 dan 2.Netherlands: KITLV. 